\title{
Thymoquinone exhibits anti-inflammatory, antioxidant, and immunomodulatory effects on allergic airway inflammation
}

\author{
Timokinon allerjik solunum yolu inflamasyonu üzerine anti-inflamatuar, antioksidan \\ ve immünomodülatör etkiler gösterir
}

\author{
Ali Parlar ${ }^{1}$, Seyfullah Oktay Arslan ${ }^{2}$
}

Abstract

Aim: Asthma is an allergic disease causing mucus secretion, release various pro-inflammatory mediators such as tumor necrosis factor- $\alpha(\mathrm{TNF}-\alpha)$ and interleukins. The aim of this study was to evaluate the effect of thymoquinone (TQ) on allergic airway inflammation in rats.

Methods: Allergic airway inflammation induced by ovalbumin (OVA) challenge in sensitized-rats and effect of TQ were studied. Inflammatory cells, interleukin (IL)-6 and TNF- $\alpha$ in bronchoalveolar lavage (BAL) fluid, and lipid peroxidation (LPO) in lung tissue were measured. Microvascular leakage was detected by Evans blue dye leakage in airway tissues.

Results: Tidal volume was significantly lower in OVA group $(1.4 \pm 0.07 \mathrm{ml})$ than control group $(1.9 \pm 0.04 \mathrm{ml})(\mathrm{p}$ $=0.002)$, while breathing frequency was significantly higher in OVA group (135.3 \pm 12.9 min-1) than contro group $(\mathrm{p}=0.017)$. In terms of tidal volume, statistical significance between TQ30 and OVA groups was found $(1.8 \pm 0.07 \mathrm{ml})(\mathrm{p}=0.008)$, while in terms of breathing frequency, no significance was found between both of them (126.7 \pm 7.3$)$. Total white blood cell count was significantly higher in OVA group $(1,376.8 \pm 136.4 \mathrm{x} 103 / \mathrm{ml})$ than control group $(545.0 \pm 106.7 \times 103 / \mathrm{ml})(\mathrm{p}<0.001)$. Statistical significance was found in TQ10 $(824.7 \pm 4.5$ $\mathrm{x} 103 / \mathrm{ml})$ group when compared OVA group $(\mathrm{p}=0.036)$, while statistical significance was not found in TQ1 group $(1,282.2 \pm 137.7 \times 103 / \mathrm{ml})$. When compared OVA group $(60.3 \pm 4.9 \mathrm{pg} / \mathrm{ml})$ with control group in terms of the TNF- $\alpha$ level, statistical significance was found $(36.7 \pm 4.7 \mathrm{pg} / \mathrm{ml})(\mathrm{p}=0.011)$. The Evans blue dye level was significantly higher in OVA group $(31.8 \pm 3.6 \mathrm{ng} / \mathrm{mg}$ of tissue) than control $(12.5 \pm 1.1 \mathrm{ng} / \mathrm{mg}$ of tissue) group $(\mathrm{p}<0.001)$, and TQ10 group (16.3 $\pm 6.7 \mathrm{ng} / \mathrm{mg}$ of tissue) $(\mathrm{p}=0.002)$, and TQ30 (13.5 $\pm 1.0 \mathrm{ng} / \mathrm{mg}$ of tissue) group $(\mathrm{p}<0.001)$

Conclusion: These findings reveal that TQ could be beneficial in asthma pathophysiology due to its immunomodulatory, anti-inflammatory, and antioxidant effects.

Keywords: allergic airway inflammation, TNF- $\alpha$, microvascular leakage, ovalbumin, thymoquinone.

Öz

Amaç: Astım, mukus sekresyonuna neden olan, TNF- $\alpha$, IL'ler gibi çeşitli proinflamatuar mediatörleri salgılayan alerjik bir hastalıktır. Timokinon'un (TQ) sıçanlarda alerjik solunum yolu inflamasyonu üzerindeki etkisini değerlendirmektir.

Yöntemler: Duyarlılaştırılmış sıçanlarda ovalbumin (OVA) ile indüklen alerjik solunum yolu enflamasyonu ve TQ etkisi çalışıldı. Bronkoalveoler lavaj (BAL) sıvısında enflamatuar hücre sayıları, interlökin (IL)-6 ve tümör nekroz faktör alfa (TNF- $\alpha$ ) düzeyleri ve akciğer dokusunda lipit peroksidasyonu (LPO) seviyeleri ölçüldü. Mikrovasküler sızıntı, solunum yolu dokusunda Evans mavisi ile tespit edildi.

Bulgular: Bu çalışmada, OVA grubunda tidal hacim $(1,4 \pm 0,07 \mathrm{ml})$, kontrol grubuna göre önemli ölçüde düşük bulunmuştur $(1,9 \pm 0,04 \mathrm{ml})(\mathrm{p}=0,002)$. OVA grubunda $(135,3 \pm 12,9 \mathrm{dk}-1)$ solunum sıklı̆̆ kontrol grubuna $(\mathrm{p}=0,017)$ göre anlamlı bulunmuştur. Tidal hacim açısından TQ30 $(1,8 \pm 0,07 \mathrm{ml})$ grubu ile OVA grubu karşılaştırıldığında istatistiksel anlamlılık bulunurken $(\mathrm{p}=0,008)$, solunum frekansı açısından gruplar arasında

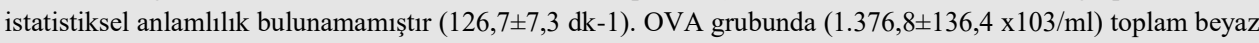

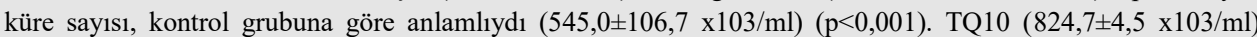
grubu ile OVA grubu arasında istatistiksel anlamlllı bulunurken ( $\mathrm{p}=0,036)$, TQ1 $(1.282,2 \pm 137,7 \mathrm{x} 103 / \mathrm{ml})$ ile OVA grubu arasında istatistiksel anlamlılık yoktu. TNF- $\alpha$ yönünden OVA grubu $(60,3 \pm 4,9 \mathrm{pg} / \mathrm{ml})$ ile kontrol grubu $(36,7 \pm 4,7 \mathrm{pg} / \mathrm{ml})$ karşılaştıııldığında, aralarında istatistiksel anlamlılık bulundu $(\mathrm{p}=0,011)$. OVA grubunda Evans mavi düzeyi (31,8 $\pm 3,6 \mathrm{ng} / \mathrm{mg}$ doku), kontrol $(12,5 \pm 1,1 \mathrm{ng} / \mathrm{mg}$ doku) $(\mathrm{p}<0,001)$, TQ10 $(16,3 \pm 6,7 \mathrm{ng} / \mathrm{mg}$ doku $(\mathrm{p}=0,002)$ ve TQ30 $(13,5 \pm 1,0 \mathrm{ng} / \mathrm{mg}$ doku $)(\mathrm{p}<0,001)$ gruplarına göre önemli derecede yüksekti.

Sonuç: Bu bulgular, timokinonun immünomodülatör, antienflamatuar ve antioksidan etkileri nedeniyle astım patofizyolojisinde yararlı olabileceğini ortaya koymaktadır.

Anahtar kelimeler: alerjik solunum yolu enflamasyonu, TNF- $\alpha$, mikrovasküler sızıntı, ovalbumin, timokinon.
${ }^{1}$ Adiyaman University, Faculty of Medicine, Department of Pharmacology, Adiyaman, Turkey.

${ }^{2}$ Ankara Yildirim Beyazit University, Faculty of Medicine, Department of Pharmacology, Ankara, Turkey.

Ethics Committee Approval: The study wass approved by the local ethical authority (2011/006). Etik Kurul Onayı: Calıșma lokal etik komite tarafından onaylanmıştır (2011/006).

Conflict of Interest: No conflict of interest was declared by the authors.

Çıkar Çatışması: Yazarlar çıkar çatışması bildirmemişlerdir.

Financial Disclosure: The authors declared that this study has received no financial support.

Finansal Destek: Yazarlar bu çalışma için finansal destek almadıklarını beyan etmişlerdir.

Geliș Tarihi / Received: 15.02.2019 Kabul Tarihi / Accepted: 16.04.2019 Yayın Tarihi / Published: 01.08.2019

Sorumlu yazar / Corresponding author:

Seyfullah Oktay Arslan

Adres/Address: Üniversiteler Mah. İhsan Doğramacı Bulvarı Ankara Atatürk Eğitim Araștırma Hastanesi Yanı Bilkent, Cankaya, Ankara, Turkey.

e-posta: soarslan@gmail.com

Tel/Phone: +90 5337333150

Copyright (C) ACEM 


\section{Introduction}

Allergic airway inflammation, asthma, is still a common problem in clinic, for especially children health. Inflammatory cells, mast cells, macrophages, eosinophils, lymphocytes, basophiles, neutrophils, and platelets, are recruited to allergic airway tissues. These are capable of synthesizing and releasing pro-inflammatory mediators, mainly interleukin (IL) and tumor necrosis factor alpha (TNF- $\alpha$ ) that produce many effects in the airways, including bronchospasm, plasma extravasations, mucus secretion, neural effects, and activation of inflammatory cells [1]. Studies from the past decade have confirmed that eosinophilic infiltration causes mild asthma, but infiltration of neutrophils and increased interleukins occur in severe asthma [2,3].

Thymoquinone (TQ, C10H12O2) is the main bioactive component of the volatile oil of the black seed (Nigella sativa, Ranunculaceae family). Nigella sativa is known for its medical use as an antispasmodic, anti-inflammatory and anti-oxidant especially against gastrointestinal disorders, respiratory ailments, and antineoplastic medicines [4-6]. There is evidence of relaxant effects of volatile oil from this plant on isolated tracheal muscles of guinea pigs [4]. El-Tahir et al. [6] reported that the volatile oil from Nigella sativa protected guinea pigs against histamineinduced bronchospasm. Recent research papers have shown that the potential immunomodulatory and immunotherapeutic potential of TQ is linked to its antioxidant, antihistaminic and anti-inflammatory properties [7, 8]. TQ improves both oxygenation and compliance in human gastric acid induced acute lung injury, in rat, by bronchodilation and preventing heavy inflammatory response [9]. Houghton et al. [10] reported that TQ have an anti-inflammatory action through inhibition of eicosanoid generation and membrane LPO. TQ attenuates acetic acid induced colitis as evidenced by its ability to inhibit the release of the mediators, platelet activating factor (PAF) and histamine, also the prevention of glutathione (GSH) depletion and LPO points to antioxidant property [7], and attenuates ethanol induced gastric damage via inhibition of LPO and reversed GSH depletion in rats [11]. Moreover, newer paper indicates that intraperitoneal injection of TQ before the ovalbumin (OVA) challenge attenuated airway inflammation as demonstrated by the significant decrease in levels of leukotriene (LT)-B4 and LTC4, Th2 cytokines, lung eosinophilia, and goblet cell hyperplasia, all of which are characteristics of airway inflammation. This attenuation of airway inflammation was concomitant to the inhibition of cyclooxygenase (COX)-2 protein expression and prostaglandin (PG)-D2 production [12]. TQ also showed a significant effect in inhibiting IL-4, IL-5 and IL-13 in the bronchoalveolar lavage (BAL) fluid, it did show a slight effect on in vitro production of IL-4 by cultured lung cells stimulated with OVA antigen [13].

OVA sensitization and aerosol challenge elicits inflammatory cell infiltration, reactive oxygen species production, antioxidant enzymes, LPO, cytokines release into BAL fluid or lung tissue, microvascular plasma leakage in airway tissues, and respiratory abnormalities, in rats or other experimental animals [1, 14-19]. Therefore, in the present study we used an animal model of allergic airway inflammation, as asthma like reaction, to elucidate the mechanisms of possible therapeutic effect of TQ.

\section{Material and methods}

\section{Chemicals}

In this study, the following drugs and chemicals were used: Ovalbumin (grade V), thiobarbituric acid (TBA), trichloroacetic acid (TCA) thymoquinone and formamide (Sigma, St. Lous, M.O., USA); Evans blue dye (Fluka Chemie GmbH, Buchs, Switzerland); thiopental sodium (Pentothal sodium, Abbott Lab. Ltd. Sti, Turkiye); aluminum hydroxide. Ovalbumin was dissolved in $0.9 \%$ sodium chloride. TQ was dissolved in $10 \%$ ethanol in $0.9 \%$ saline.

\section{Animals and Treatments}

After ethics committee approved for the animals ((DÜHADYEK) 2011/006), male Wistar rats weighing 180-200 g were obtained from the Experimental Animal Unite of Duzce University and housed at $22 \pm 1{ }^{\circ} \mathrm{C}$ under $12: 12 \mathrm{~h}$ light-dark cycle. Animals were allowed free access to standard laboratory chow and water. All procedures complied with the standards for the care and use of animals as stated in Guide for the Care and Use of Laboratory Animals.

Groups were subdivided as series A for inflammatory cells infiltration, cytokines, LPO, lung function tests and series B for microvascular leakage detection ( $\mathrm{n}=7$, for each subgroup).

1. Unsensitized control group (Control): Rats were injected with only saline $(1 \mathrm{ml}$, ip.) and treated with an aerosol of saline.

2. Sensitized and challenged group (OVA): Rats were sensitized and challenged with OVA. Vehicle group as subgroup was TQ's vehicle (10\% ethanol in $0.9 \%$ saline)

3. TQ administrated group (TQ): Sensitized rats were treated with TQ, three times as $30 \mathrm{~min}$, one and two days before the OVA provocation. The three doses of TQ, as 1, 10, and 30 $\mathrm{mg} / \mathrm{kg}$, were treated for the studies of inflammatory cell counts, the analysis of lipid peroxidation (LPO), and IL-6 and TNF- $\alpha$ levels. Median effective inhibition dose of TQ $(10 \mathrm{mg} / \mathrm{kg}$, intraperitoneal) on inflammatory cells infiltration to BAL fluid was chosen for the other studies, microvascular leakages.

Sensitization and antigen challenge and evaluation of respiratory activity

Rats were sensitized and challenged with ovalbumin antigen [20]. Rats were sensitized on days 0,14 , and 21 with ovalbumin (at $100 \mu \mathrm{g}$ administered with aluminum hydroxide adjuvant at $100 \mathrm{mg}$, by intraperitoneal). Aluminum hydroxide is used as an adjuvant with ovalbumin to boost the immune response to produce more antibodies and longer-lasting immunity [21]. The sensitized rats were used for microvascular leakage studies or OVA challenge studies on days 28-30. Assessment of pulmonary function test by a noninvasive method was used to determine the severity of lung failure. Therefore, at days 28-30 to challenge with OVA and to record the respiratory abnormality, the animals, one by one, were placed in whole body respiratory chamber [22]. After stabilization of the breath pattern (within $30 \mathrm{sec}$ ), rats were challenged with an aerosol of ovalbumin ( $1 \%$ in distillated water) with an ultrasonic nebulizer device for 20 minute. The rats were withdrawn from OVA antigen exposure at the first sign of respiratory abnormality. The changes in the respiratory activity of the animals were recorded for $5 \mathrm{~min}$ after the aerosol administration, with whole body plethysmograph (Emka, Paris, France). Before experiments, animals were handled and familiarized with the apparatus to reduce stress (Figure 1).

BAL fluid collection and cell counting and analysis

To evaluate airway inflammation, all inflammatory cells in the BAL fluid were counted and classified. Hence, BAL was performed in deep sodiun thiopental $(70 \mathrm{mg} / \mathrm{kg}$, ip.) anesthetized rats. For this purpose, a total volume of $30 \mathrm{ml}$ (3 times, $10 \mathrm{ml}$ ) of PBS was injected into the lungs by the tracheal route. The BAL fluid was collected and centrifuged (170 g, $10 \mathrm{~min})$; the cellular pellet was re-suspended in $1 \mathrm{ml}$ PBS. Aliquots of cells suspensions $(90 \mu \mathrm{l})$ were stained with $10 \mu \mathrm{l}$ of $0.2 \%$ crystal violet to quantify total cells. Differential cell counting 
(neutrophils, eosinophils, and mononuclear cells) were carried out using standard morphological criteria after cytospin processing and staining with Rosenfeld's dye.

\section{IL-6 and TNF- $\alpha$ assay in BAL fluid}

IL- 6 and TNF- $\alpha$ levels in BAL fluids were measured by ELISA method according to the manufacturer's kits using guideline for users (Abcam, ab100772, ab100785, respectively). The lower limits of detection of IL- 6 and TNF- $\alpha$ were measured as $8 \mathrm{pg} / \mathrm{ml}$ and $4 \mathrm{pg} / \mathrm{ml}$, respectively.

\section{Lipid peroxidation determination in lung tissue}

After performing BAL fluid, lung lobes were excised, thawed and homogenized in isotonic saline with a polytron. The products of LPO, as MDA concentrations, according to the method of Ohkawa et al. [23]. Briefly the tissue samples were homogenized in an ice bath, ice-cold TCA by adding $10 \mathrm{ml}$ of $10 \%$ TCA per $\mathrm{g}$ of tissue, with an ultrasonic tissue homogenizer. After two consecutive centrifugations at 3,000 g for $15 \mathrm{~min}, 500$ $\mu 1$ supernatant was mixed with equal volume of $0.67 \%$ TBA and heated to $100^{\circ} \mathrm{C}$ for $15 \mathrm{~min}$. The absorbance of the samples was then measured by using spectrophotometry at $535 \mathrm{~nm}$. Each assay was performed in duplicate.

\section{Microvascular leakage}

Microvascular leakage was measured as described by previous study [24]. Briefly, sensitized rats were anaesthetized with $\mathrm{Na}$ thiopental $(50 \mathrm{mg} / \mathrm{kg})$ and given Evans blue dye $(25$ $\mathrm{mg} / \mathrm{kg}$ as $25 \mathrm{mg} / \mathrm{ml}$ in saline, intravenously). Two minute later, they were given ovalbumin ( $2 \mathrm{mg} / \mathrm{kg}$, intravenous) or saline. Cervical jugular vein was used for intravenous injections. Animals were killed by $\mathrm{Na}$ thiopental overdose $(100 \mathrm{mg} / \mathrm{kg}$, intraperitoneal), 15 minutes after allergen administration.

The chest was opened and an incision made in the left ventricle, then a cannula was inserted through the left ventricle and into the ascending aorta and, approximately $150 \mathrm{ml}$ of sterile saline $(0.9 \%)$ was perfused at a pressure of $100 \mathrm{mmHg}$. The heart and lungs were removed en bloc. The pulmonary airways were each placed in $2 \mathrm{ml}$ of formamide for $18 \mathrm{~h}$ at $40{ }^{\circ} \mathrm{C}$ to facilitate the extraction of Evans blue dye. The absorbencies of the resulting extracts were determined against standard concentrations of Evans blue at a $620 \mathrm{~nm}$ wavelength. The measurements were duplicated. The results are expressed as concentration of Evans blue dye (ng/mg of wet tissue).

The experimental protocol for the effect of TQ was put on ovalbumin-induced microvascular leakage in the airways and plasma leakage was assessed as described above. Sensitized rats were received TQ $(10 \mathrm{mg} / \mathrm{kg}$, intraperitoneal) $20 \mathrm{~min}$ before ovalbumin injected. The animals were killed $15 \mathrm{~min}$ after ovalbumin and the tissues were removed for Evans blue dye extraction.

Asthma was induced by intraperitoneal administration of $100 \mu \mathrm{g}$ OVA/100 mg aluminum hydroxide $(\mathrm{Al}(\mathrm{OH}) 3)$ suspended in $1 \mathrm{ml}$ saline for 0,14 and 21 th days then inhalation of $1 \%$ OVA with all body nebulizer at day 28 th.

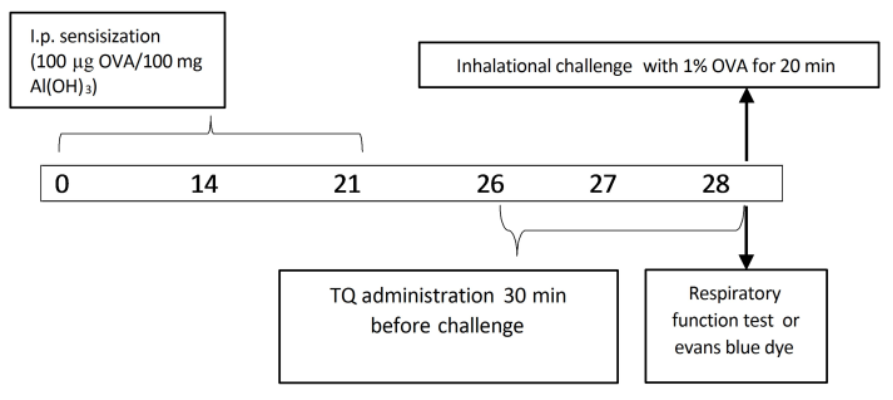

Figure 1: Schematic diagram of experimental design.

\section{Statistical evaluation}

Results are presented as means S.E.M. Statistical comparisons means were carried using one-way ANOVA followed by the Bonferroni's multiple comparison test, using Graph Pad Prism, version 3.0. A value of $\mathrm{P}<0.05$ was considered as significant.

\section{Results}

Effect of TQ on respiratory abnormality caused by ovalbumin challenge in sensitized rats

As seen in Table 1, there was a significant decrease $(p=0.002)$ in the tidal volume, whereas there was a significant increase $(\mathrm{p}=0.017)$ in the frequency of breathing of OVA group as compared to the control group. Treatment with TQ (10, and 30 $\mathrm{mg} / \mathrm{kg})$ significantly increased $(\mathrm{p}=0.046, \mathrm{p}=0.008)$ in Tidal volume, whereas the frequency of breathing was not affected significantly by TQ in treatment group as compared to OVA rats (Figure 2).
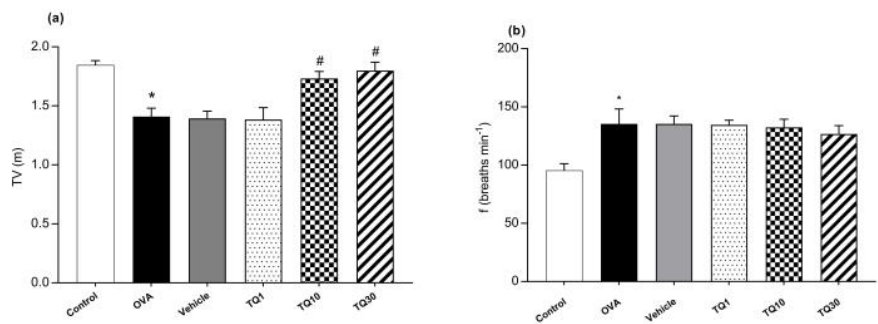

Figure 2: Effect of TQ on OVA-induced asthma in lung functions of rats.Data are expressed as mean \pm S.E.M. $(n=7)$ and one-way ANOVA followed by Bonferroni's multiple range test. ${ }^{*} \mathrm{p}<0.05$ as compared to control group, \#p $<0.05$ as compared to OVA group.

Effects of TQ on inflammatory cell infiltration in BAL fluid caused by ovalbumin challenge in sensitized rats

As shown in Figure 3, total inflammatory cells were significantly elevated in the OVA group compared with control group, clearly eosinophils and neutrophils. TQ treatment resulted in significantly reduced numbers of total inflammatory cells in the BALF from rat with OVA-induced allergic asthma, especially eosinophils and neutrophils.

Table 1: Comparison of parameters measurements between the groups.

\begin{tabular}{|c|c|c|c|c|c|c|c|c|c|c|}
\hline$(n=7)$ & Control & OVA & Vehicle & TQ1 & TQ10 & TQ30 & P1 & $\mathrm{P} 2$ & P3 & P4 \\
\hline $\mathrm{TV}(\mathrm{ml})$ & $1.9 \pm 0.04$ & $1.4 \pm 0.07 *$ & $1.4 \pm 0.06$ & $1.38 \pm 0.1$ & $1.73 \pm 0.06^{\#}$ & $1.80 \pm 0.07^{\#}$ & 0.002 & 1 & 0.047 & 0.008 \\
\hline $\mathrm{f}$ (breaths $\left.\min ^{-1}\right)$ & $95.3 \pm 5.9$ & $135.3 \pm 12.9^{*}$ & $135.3 \pm 8.9$ & $134.50 \pm 4.0$ & $132.33 \pm 0.06$ & $126.67 \pm 3.3$ & 0.017 & 1 & 1 & 1 \\
\hline Total WBC in BALF $\left(\times 10^{3} / \mathrm{ml}\right)$ & $545.0 \pm 106.7$ & $1,376.8 \pm 136.4^{*}$ & $1,373.2 \pm 10.0$ & $1,282.17 \pm 137.7$ & $824.67 \pm 4.5^{\#}$ & $621.33 \pm 5.5^{\#}$ & $<0.001$ & 1 & 0.036 & 0.001 \\
\hline Lymphocyte $\left(\times 10^{3} / \mathrm{ml}\right)$ & $146.2 \pm 25.3$ & $410.2 \pm 38.8^{*}$ & $395.7 \pm 5.5$ & $380.17 \pm 49.9$ & $213.33 \pm 5.5^{\#}$ & $166.17 \pm 2.2^{\#}$ & 0.002 & 1 & 0.036 & 0.004 \\
\hline Eosinophil $\left(\times 10^{3} / \mathrm{ml}\right)$ & $95.1 \pm 19.8$ & $287.3 \pm 21.3 * *$ & $282.5 \pm 4.4$ & $242.17 \pm 20.8$ & $140.06 \pm 1.1^{\# \#}$ & $121.83 \pm 8.9^{\# \#}$ & $<0.001$ & 1 & 0.001 & $<0.001$ \\
\hline Monocyte $\left(\times 10^{3} / \mathrm{ml}\right)$ & $57.0 \pm 13.8$ & $125.0 \pm 12.0 *$ & $131.1 \pm 2.2$ & $118.01 \pm 9.6$ & $69.33 \pm 5.6^{\#}$ & $67.02 \pm 0.02^{\#}$ & 0.002 & 1 & 0.019 & 0.013 \\
\hline Neutrophil $\left(\mathrm{x} 10^{3} / \mathrm{ml}\right)$ & $214.5 \pm 40.0$ & $749.2 \pm 79.4 * *$ & $765.8 \pm 4.4$ & $593.83 \pm 81.3$ & $382.67 \pm 1.1^{\#}$ & $346.33 \pm 8.9^{\#}$ & $<0.001$ & 1 & 0.006 & 0.002 \\
\hline IL-6 in BALF (pg/mL) & $23.7 \pm 1.8$ & $26.8 \pm 1.5$ & $26.8 \pm 1.9$ & $21.67 \pm 1.8$ & $20.67 \pm 2.3$ & $20.67 \pm 2.3$ & 0.657 & 1 & 0.205 & 0.091 \\
\hline TNF-a in BALF $(\mathrm{pg} / \mathrm{mL})$ & $36.7 \pm 4.7$ & $60.3 \pm 4.9 *$ & $63.7 \pm 5.7$ & $59.02 \pm 4.9$ & $40.33 \pm 2.5^{\#}$ & $39.83 \pm 3.2^{\#}$ & 0.011 & 1 & 0.050 & 0.040 \\
\hline MDA in lung tissue $(\mathrm{nmol} / \mathrm{g})$ & $8.3 \pm 1.1$ & $15.9 \pm 1.2 *$ & $15.3 \pm 8.8$ & $14.67 \pm 1.7$ & $9.67 \pm 6.7^{\#}$ & $9.32 \pm 5.5^{\#}$ & 0.003 & 1 & 0.026 & 0.016 \\
\hline Evans blue dye (ng/mg of tissue) & $12.5 \pm 1.1$ & $31.8 \pm 3.6 * *$ & $31.1 \pm 7.8$ & $24.98 \pm 2.9$ & $16.33 \pm 6.7^{\#}$ & $13.50 \pm 1.0^{\#}$ & 0.001 & 0.992 & 0.002 & 0.001 \\
\hline
\end{tabular}


Effects of TQ on IL-6 and TNF-a levels in BAL fluid caused by ovalbumin challenge in sensitized rats

As demonstrated in Figure 4, IL-6 level in BAL fluid was not significantly changed both in OVA and TQ groups as compared to control group (a). However, TNF- $\alpha$ level in BAL fluid was significantly elevated in the OVA group as compared to the control group $(\mathrm{p}=0.011)$, while TNF- $\alpha$ level in BAL fluid was lower in the TQ group than those in the OVA group $(\mathrm{p}=0.040)(\mathrm{b})$.

\section{ovalbumin challenge in sensitized rats \\ Effect of TQ on MDA level in lung tissue caused by}

Malondialdehyde (MDA) level was increased in lung tissue of the OVA group as compared to the control group $(\mathrm{p}=0.003)$. As shown in Figure 5, TQ treatment decreased MDA level when compared to OVA group $(\mathrm{p}=0.016)$.

Effect of TQ on ovalbumin induced microvascular protein leakage in sensitized rats

The $30 \mathrm{mg} / \mathrm{kg}$ dose of TQ significantly increased microvascular leakage in airway tissue $(\mathrm{p}<0.001)$. TQ $(10 \mathrm{mg} / \mathrm{kg}$, intraperitoneal) given $20 \mathrm{~min}$ prior to OVA challenge decreased the high microvascular leakage response in airway tissues $(\mathrm{p}=0.002)$ (Figure 6)
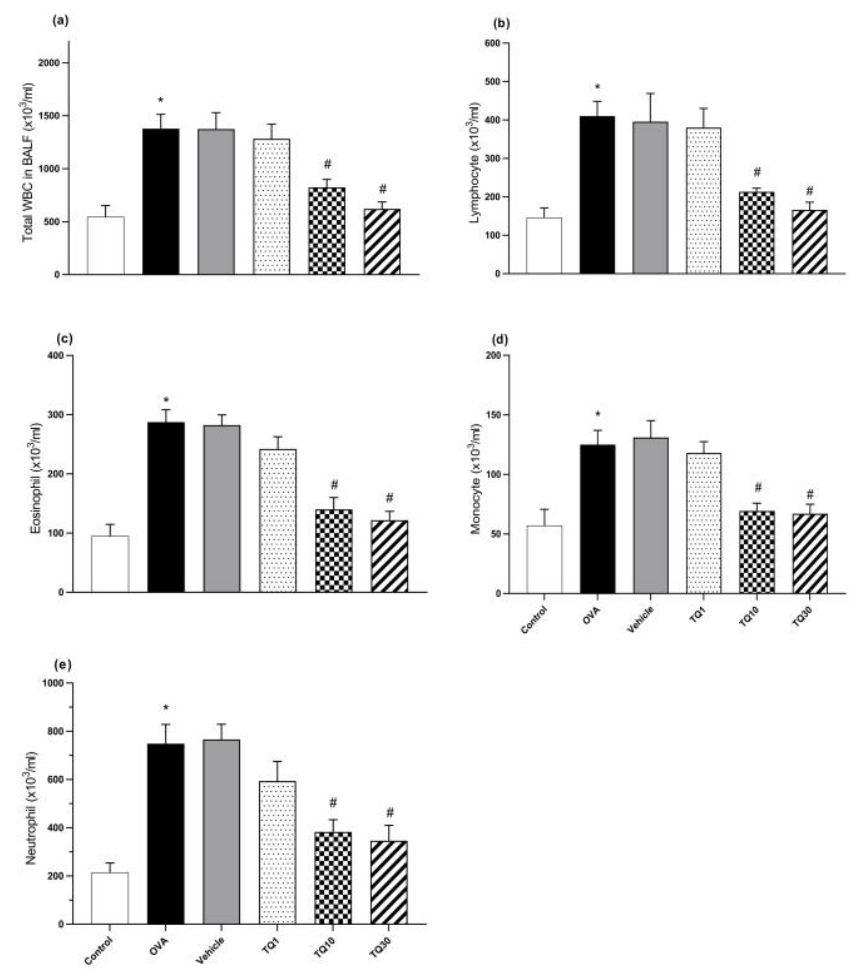

Figure 3: Effect of TQ on OVA-induced asthma in count of total WBC (a), lymphocyte (b), eosinophil (c), monocyte (d), and neutrophil (e) in BALF. Data are expressed as mean \pm S.E.M. $(n=7)$ and one-way ANOVA followed by Bonferroni's multiple range test. ${ }^{*} \mathrm{p}<0.001$ as compared to control group, \#p $<0.05$ as compared to OVA group.
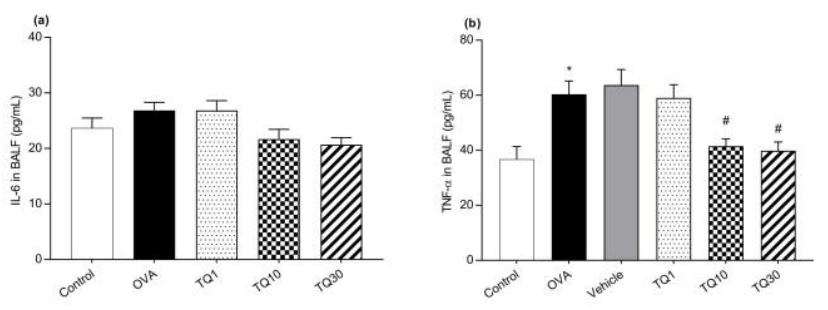

Figure 4: Effect of TQ on OVA-induced asthma in IL-6 (a) and TNF- $\alpha$ level (b) in BALF of rats. Data are expressed as mean \pm S.E.M. $(n=7)$ and one-way ANOVA followed by Bonferroni's multiple range test. $* \mathrm{p}<0.05$ as compared to control group, \#p $<0.05$ as compared to OVA group.

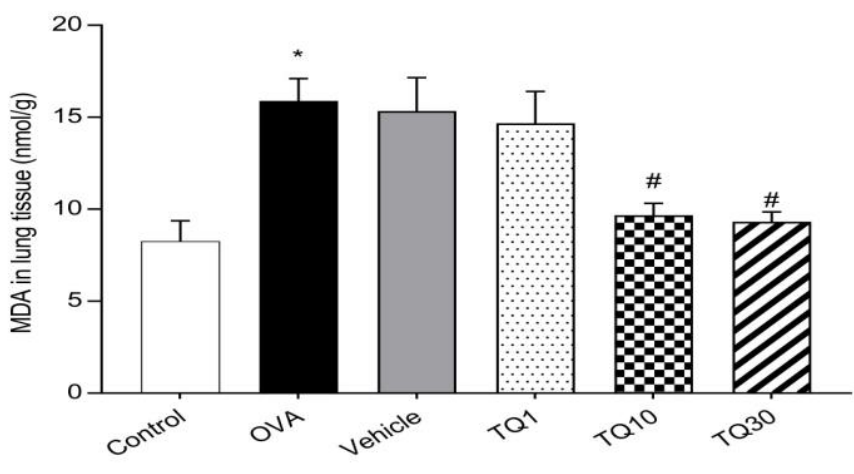

Figure 5: Effect of TQ on OVA-induced asthma in MDA content in BALF of rats. Data are expressed as mean \pm S.E.M. $(n=7)$ and one-way ANOVA followed by Bonferroni's multiple range test. ${ }^{*} p<0.05$ as compared to control group, \#p $<0.05$ as compared to OVA group.

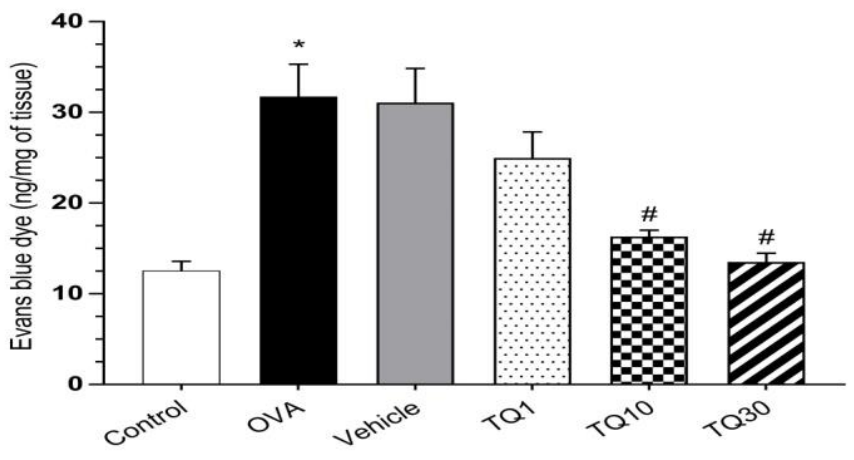

Figure 6: Effect of TQ on OVA-induced asthma in microvascular leakage in lung of rats. Data are expressed as mean \pm S.E.M. $(n=7)$ and one-way ANOVA followed by Bonferroni's multiple range test. ${ }^{*} \mathrm{p}<$ 0.05 as compared to control group, \#p $<0.05$ as compared to OVA group.

\section{Discussion}

The efficacy of anti-asthmatic drugs depends on the asthma pathophysiology: cell recruitment, edema, mediators release, interleukins release, oxidative stress, bronchospasm and respiratory abnormality. The anti-asthmatic effects seen for TQ might be produced due to several different mechanisms.

In this study, we investigated the effect of TQ on the allergic airway inflammation provoked by ovalbumin challenge in the pulmonary tissue of actively sensitized rats. Our results demonstrated that TQ administration effectively inhibit the respiratory abnormality, microvascular leakage, leukocyte influx, including eosinophils, LPO, and pro-inflammatory cytokine release such as TNF- $\alpha$, in allergic airway inflammation.

Papers have showed that inflammatory insult to the lungs resulted in an alteration in respiration. Thus, determination of respiratory function test is used for diagnosis of the nature and degree of lung sensitivity. The results of the present research are in accordance with the findings of the previous study where OVA-induced rats showed altered lung functions [25]. However, administration of TQ (10-30 $\mathrm{mg} / \mathrm{kg})$ showed significant restoration of these effected parameters.

Intensity of inflammatory immune responses is controlled by recruitment of inflammatory cells into inflammatory area. Inflammatory cells, as leukocytes, especially eosinophils release inflammatory mediators give a major contribution to the pathogenesis of allergic airway inflammation. Inflammatory cells elevated in BAL fluid are also source of leukotrienes that are formed by the breakdown of a membrane constituent, arachidonic acid, via the 5-lipoxygenase enzyme pathway. Leukotrienes may a play an important role in attracting neutrophils and eosinophils into airways, and produce 
bronchoconstriction, mucus secretion, microvascular leakage, airway edema, and neuronal interactions [14, 17, 26-28]. Therefore, the reduction of leukocyte infiltration may be a mechanism for the beneficial effect of TQ. The results of this study showed that pretreatment of sensitized animals with TQ suppressed the eosinophilic and neutrophilic inflammation.

This is the report to comprehensively demonstrate that TQ inhibits microvascular protein leakage induced by OVA. The enhanced microvascular leakage associated edema in the airway wall and lumen that were observed in our animal model of allergic airway inflammation may play a role in its pathogenesis by contributing to narrowing of airways, and respiratory abnormality. The leakage of plasma proteins from the microvasculature into airway tissue is an important consequence of asthmatic airway inflammation. The leakage of plasma proteins was evaluated by measuring the tissue accumulation of Evans blue dye, which binds to proteins. The present experimental model was undertaken on ovalbumin-sensitized rats that were evoked with intravenously administration of ovalbumin. Our results show that ovalbumin can cause microvascular leakage into the airway tissue. The increase in airway microvascular leakage induced by ovalbumin could be inhibited by pretreatment with TQ $(10$, and $30 \mathrm{mg} / \mathrm{kg})$. The inhibitory mechanism of plasma leakage and eosinophil enrichment seems to be closely associated with inhibition of histamine release from mast cells. Previous studies show that microvascular airway leakage is increased in sensitized rats, mice, and guinea pigs by ovalbumin [17, 25, 29-32], and capsaicin $[33,34]$.

The increased airway microvascular leakage induced by intravenous application of ovalbumin to ovalbumin-sensitized rats could be a result of several factors. Ovalbumin antigen may elicit the release of inflammatory mediators from inflammatory and structural cells in airways $[16,20]$. These mediators can lead to the typical pathophysiological changes of asthma, including microvascular plasma leakage. Many mediators are released in asthma, and it is clear that these mediators interact with each other in some way. Mediators may act synergistically to enhance each other's effects, or one mediator may modify the release or action of another mediator [22]. The effect of TQ on airway microvascular leakage in sensitized rats might be explained by its inhibitory action on histamine $[35,36]$. So it seems that it is logical to focus on the further studies to understand the interaction of opioid and histamine on microvascular leakage in airway of sensitized animals. As another mechanism, neurogenic inflammation may be stimulated by ovalbumin antigen [34, 37]. This effect may be relevant by release of tachykinins from sensory nerves. Among the tachykinins, substance $\mathrm{P}$ is the most potent to cause leakage. It can induce microvascular leakage in guinea pig airways when it is administered alone [38, 39]. It is known that cytokines as TNF- $\alpha$ can alter the sensitivity of the sensory nerves for neurogenic stimulants [40]. TQ can reduce the inflammation mediated by sensory nerves in the airways; this effect may be associated with the direct or indirect inhibition of tachykinin and neuropeptide release. This hypothesis should be supported by more detail further studies demonstrated that TQ inhibits neurogenic inflammation in sensitized animals.

There is increasing evidence that oxidative stress and reactive oxygen species are involved in allergic airway inflammation. Inflammatory cells activated in allergic airway inflammation produce reactive oxygen species. ROS may damage airway wall, resulting in increased bronchoconstriction, plasma leakage, mucus secretion, and induce LPO, resulting in the formation of additional mediators. Superoxide and hydrogen peroxide may interact in the presence of free iron to form the highly reactive hydroxyl radicals. Oxidative stress describes an imbalance between ROS and antioxidant. In this study the MDA, LPO products of oxidation were studied in lung tissue. We observed an increase in LPO in lung tissue of allergic airway inflammation model of rats. Therefore, it is possible that beneficial effect of TQ may be related to its anti-peroxide properties. Previous studies have shown the same effect in other disease models [10, 24].

Based on our present results, we conclude that TQ effectively inhibits TNF- $\alpha$ that it is considered important mediators of inflammation and is considered to be a main of inflammatory cytokine production [12]. Pro-inflammatory cytokines are involved in allergic airway inflammatory. In the present study IL-6 and TNF- $\alpha$ levels in BAL fluid were determined after OVA challenge in sensitized rats. TNF- $\alpha$ potently stimulates airway epithelial cells to produce other cytokines, and increases the expression of intracellular adhesion molecules that are the adhesion of inflammatory cells, such as neutrophils and eosinophils at the airway surface. Previous studies shown that TNF- $\alpha$ is present in the BAL fluid from asthmatic patients [41], and also released in the BAL fluid from allergen challenged animals [42]. TNF- $\alpha$ target different cells such as endothelial cells, macrophages and neutrophils. TNF- $\alpha$ leads to the increased production of macrophages and stimulates their differentiation and activation. TNF- $\alpha$ augment inflammatory cascades by triggering macrophages to release other pro-inflammatory cytokines such as IL-6, reactive oxygen/nitrogen species and lipid mediators, which are important in ovalbumin-induced asthma like reaction. The current results showed that TQ can modulate the marked increase in TNF- $\alpha$ levels during ovalbumin sensitization and provocation, which may explain, at least in part, its beneficial effect during allergic reaction of lung tissues. However, it was not observed IL-6 levels in BAL fluids of ovalbumin sensitized and provoked rats.

For all that, limitation of this study is that asthma like reaction was examined in rats and the results cannot be fully extrapolated or adapted to clinical pathophysiological conditions. Thus the present data need to support by the results of various clinical circumstances of asthma.

Taken together, these findings suggest a potential therapeutic effect of TQ against allergic airway inflammation that would be translated to clinical setting in humans for management of allergic diseases, particularly asthma-like disease manner. In conclusion, we demonstrate that administration of TQ attenuates allergen-evoked eosinophilic inflammation in the rat.

\section{References}

1. Kim SY, Kim T-B, Moon K, Kim TJ, Shin D, Cho YS, et al. Regulation of pro-inflammatory responses by lipoxygenases via intracellular reactive oxygen species in vitro and in vivo. Exp Mol Med. 2008;40:461.

2. Halwani R, Sultana A, Vazquez-Tello A, Jamhawi A, Al-Masri AA, AlMuhsen S. Th-17 regulatory cytokines IL-21, IL-23, and IL-6 enhance neutrophil production of IL-17 cytokines during asthma. J Asthma. 2017;54:893-904.

3.Roussel L, Houle F, Chan C, Yao Y, Berube J, Olivenstein R, et al. IL-17 Promotes p38 MAPK-Dependent Endothelial Activation Enhancing Neutrophil Recruitment to Sites of Inflammation. J Immunol. 2010;184:4531-7.

4.Boskabady MH, Javan H, Sajady M, Rakhshandeh H. The possible prophylactic effect of Nigella sativa seed extract in asthmatic patients. Fundam Clin Pharmacol. 2007;21:559-66.

5.Ahmad A, Husain A, Mujeeb M, Khan SA, Najmi AK, Siddique NA, et al. A review on therapeutic potential of Nigella sativa: A miracle herb. Asian Pac J Trop Biomed. 2013;3:337-52.

6.el Tahir KE, Ashour MM, al-Harbi MM. The respiratory effects of the volatile oil of the black seed (Nigella sativa) in guinea-pigs: elucidation of the mechanism(s) of action. Gen Pharmacol. 1993;24:1115-22.

7.Salem ML. Immunomodulatory and therapeutic properties of the Nigella sativa L. seed. Int. Immunopharmacol. 2005;5:1749-70. 
8.Khader M, Bresgen N, Eckl PM. In vitro toxicological properties of thymoquinone. Food Chem Toxicol 2009;47:129-33.

9.Isik AF, Kati I, Bayram I, Ozbek H. A new agent for treatment of acute respiratory distress syndrome: thymoquinone. An experimental study in a rat model. Eur J Cardio-Thoracic Surg. 2005;28:301-5.

10.Houghton P, Zarka R, de las Heras B, Hoult J. Fixed Oil of Nigella sativa and Derived Thymoquinone Inhibit Eicosanoid Generation in Leukocytes and Membrane Lipid Peroxidation. Planta Med. 1995;61:33-6.

11.Arslan SO, Gelir E, Armutcu F, Coskun O, Gurel A, Sayan H, et al. The protective effect of thymoquinone on ethanol-induced acute gastric damage in the rat. Nutr Res. 2005;25:673-80.

12.El Mezayen R, El Gazzar M, Nicolls MR, Marecki JC, Dreskin SC, Nomiyama $\mathrm{H}$. Effect of thymoquinone on cyclooxygenase expression and prostaglandin production in a mouse model of allergic airway inflammation. Immunol Lett. 2006;106:72-81.

13.El Gazzar M, El Mezayen R, Marecki JC, Nicolls MR, Canastar A, Dreskin SC. Anti-inflammatory effect of thymoquinone in a mouse model of allergic lung inflammation. Int. Immunopharmacol. 2006;6:1135-42.

14.Vuolo F, Petronilho F, Sonai B, Ritter C, Hallak JEC, Zuardi AW, et al. Evaluation of Serum Cytokines Levels and the Role of Cannabidiol Treatment in Animal Model of Asthma. Mediators Inflamm. 2015;2015:538670.

15. Drevytska T, Morhachov R, Tumanovska L, Portnichenko G, Nagibin V, Boldyriev $\mathrm{O}$, et al. shRNA-Induced Knockdown of a Bioinformatically Predicted Target IL10 Influences Functional Parameters in Spontaneously Hypertensive Rats with Asthma. J Integr Bioinform. 2018. 2018;15(4). doi: 10.1515/jib-2018-0053.

16. Shinagawa K, Kojima M. Mouse Model of Airway Remodeling. Am J Respir Crit Care Med. 2003;168:959-67.

17. Campos MG, Toxqui E, Tortoriello J, Oropeza M V, Ponce H, Vargas $\mathrm{MH}$, et al. Galphimia glauca organic fraction antagonizes LTD(4)-induced contraction in guinea pig airways. J Ethnopharmacol. 2001;74:7-15.

18. Chen Y-H, Wu R, Geng B, Qi Y-F, Wang P-P, Yao W-Z, et al Endogenous hydrogen sulfide reduces airway inflammation and remodeling in a rat model of asthma. Cytokine. 2009;45:117-23.

19. Escott KJ, Belvisi MG, Birrell MA, Webber SE, Foster ML, Sargent CA. Effect of the p38 kinase inhibitor, SB 203580, on allergic airway inflammation in the rat. Br J Pharmacol. 2000;131:173-6.

20. Mukherjee AA, Kandhare AD, Rojatkar SR, Bodhankar SL. Ameliorative effects of Artemisia pallens in a murine model of ovalbumininduced allergic asthma via modulation of biochemical perturbations. Biomed Pharmacother. 2017;94:880-9.

21. Li X, Hufnagel S, Xu H, Valdes SA, Thakkar SG, Cui Z, et al. Aluminum (Oxy)Hydroxide Nanosticks Synthesized in Bicontinuous Reverse Microemulsion Have Potent Vaccine Adjuvant Activity. ACS Appl Mater Interfaces. 2017;9:22893-901.

22. Xie Q-M, Chen J-Q, Shen W-H, Bian R-L. Correlative changes of interferon-gamma and interleukin-4 between cortical layer and pulmonary airway of sensitized rats. Acta Pharmacol Sin. 2002;23:248-52.

23. Ohkawa H, Ohishi N, Yagi K. Assay for lipid peroxides in animal tissues by thiobarbituric acid reaction. Anal Biochem. 1979;95:351-8.

24. Oktay ARSLAN S. Morphine modulates microvascular leakage dosedependently in the airway of ovalbumin-sensitized rats. Turk J Med Sci. 2010;40:279-86.

25. Aun M, Bonamichi-Santos R, Arantes-Costa FM, Kalil J, GiavinaBianchi P. Animal models of asthma: utility and limitations. J. Asthma Allergy. 2017;10:293-301.

26. Wenzel SE, Szefler SJ, Leung DYM, Sloan SI, Rex MD, Martin RJ. Bronchoscopic Evaluation of Severe Asthma. Am J Respir Crit Care Med. 1997;156:737-43.

27. Dong F, Wang C, Duan J, Zhang W, Xiang D, Li M. Puerarin attenuates ovalbumin-induced lung inflammation and hemostatic unbalance in rat asthma model. Evid. Based Complement Alternat Med. 2014;2014:726740.

28. Marefati N, Eftekhar N, Kaveh M, Boskabadi J, Beheshti F, Boskabady MH. The Effect of Allium cepa Extract on Lung Oxidant, Antioxidant, and Immunological Biomarkers in Ovalbumin-Sensitized Rats. Med Princ Pract. 2018;27:122-8.

29. Olivenstein R, Du T, Xu LJ, Martin JG. Microvascular Leakage in the Airway Wall and Lumen During Allergen Induced Early and Late Responses in Rats. Pulm. Pharmacol Ther. 1997;10:223-30.

30. Ikezono K, Kamata M, Mori T. Adrenal Influences on the Inhibitory Effects of Procaterol, a Selective Beta-Two-Adrenoceptor Agonist, on Antigen-Induced Airway Microvascular Leakage and Bronchoconstriction in Guinea Pigs. Pharmacology. 2005;73:209-15.

31. Underwood SL, Lewis SA, Raeburn D. RP 58802B, a long-acting beta 2-adrenoceptor agonist: assessment of antiasthma activity in the guinea-pig in vivo. Pulm Pharmacol. 1992;5:203-12.
32. Ikemura T, Sasaki Y, Ohmori K. Inhibitory effect of NPC-17731 on BKinduced and antigen-induced airway reactions in guinea-pigs. Clin Exp Allergy. 1998;28:635-43.

33. Birrell MA, Crispino N, Hele DJ, Patel HJ, Yacoub MH, Barnes PJ, et al. Effect of dopamine receptor agonists on sensory nerve activity: possible therapeutic targets for the treatment of asthma and COPD. Br J Pharmacol. 2002;136:620-8.

34. Rodger IW, Tousignant C, Young D, Savoie C, Chan CC. Neurokinin receptors subserving plasma extravasation in guinea pig airways. Can J Physiol Pharmacol. 1995;73:927-31.

35. Mauser PJ, House A, Jones H, Correll C, Boyce C, Chapman RW. Pharmacological characterization of the late phase reduction in lung functions and correlations with microvascular leakage and lung edema in allergen-challenged Brown Norway rats. Pulm Pharmacol Ther. 2013;26:677-84.

36. Tokuyama K, Nishimura H, lizuka K, Kato M, Arakawa H, Saga R, et al. Effects of Y-27632, a Rho/Rho Kinase Inhibitor, on Leukotriene D(4)and Histamine-Induced Airflow Obstruction and Airway Microvascular Leakage in Guinea Pigs in vivo. Pharmacology. 2002;64:189-95.

37. Ramalho R, Almeida J, Beltrão M, Pirraco A, Costa R, Sokhatska O, et al. Neurogenic inflammation in allergen-challenged obese mice: a missing link in the obesity-asthma association? Exp Lung Res. 2012;38:316-24.

38. Tamaoki J, Yamawaki I, Taira M, Nagano Y, Nakata J, Nagai A. Effect of cromolyn on adenosine-induced airway microvascular leakage in sensitized rats. Eur Respir J. 1999;14:1082-7.

39. Planquois JM, Mottin G, Artola M, Lagente V, Payne A, Dahl S. Effects of phosphodiesterase inhibitors and salbutamol on microvascular leakage in guinea-pig trachea. Eur J Pharmacol. 1998;344:59-66.

40. Vermeersch S, Benschop RJ, Van Hecken A, Monteith D, Wroblewski VJ, Grayzel D, et al. Translational Pharmacodynamics of Calcitonin GeneRelated Peptide Monoclonal Antibody LY2951742 in a Capsaicin-Induced Dermal Blood Flow Model. J Pharmacol Exp Ther. 2015;354:350-7.

41. Giuffrida MJ, Valero N, Mosquera J, Duran A, Arocha F, Chacín B, et al. Increased Systemic Cytokine/Chemokine Expression in Asthmatic and Non-asthmatic Patients with Bacterial, Viral or Mixed Lung Infection. Scand J Immunol. 2017;85:280-90.

42. Wu W, Li Y, Jiao Z, Zhang L, Wang X, Qin R. Phyllanthin and hypophyllanthin from Phyllanthus amarus ameliorates immuneinflammatory response in ovalbumin-induced asthma: role of IgE, Nrf2, iNOs, TNF- $\alpha$, and IL's. Immunopharmacol Immunotoxicol. 2018:1-13. 